\title{
The Sensitivity Analysis of the International Investment Decision Model
}

\author{
Tsui-Yii Shih" ${ }^{*}$ and Charles V. Trappey ${ }^{2}$ \\ ${ }^{1}$ Department of Business Administration, LungHwa University of Science and Technology 300, Sec. 1, WanShou Rd., \\ GuiShan Shiang, Taoyuan County 333, Taiwan \\ ${ }^{2}$ Department of Management Science, National Chiao Tung University, 1001, Ta Hsueh Road, Hsinchu 300, Taiwan
}

\begin{abstract}
Johanson and Vahlne's research provides a starting point for building a model that suits general international investments and decision making processes. This research derives an integer programming investment decision model that also considers investment costs and the risk attitudes of firms. The sensitivity analysis of the revised model demonstrates how risk attitudes and investment costs influence the optimal investment decision. Compared to the cost factors, the influence of attitudes toward risk are the key to the overall decision making process.
\end{abstract}

Keywords: Integer programming, sensitivity analysis, internationalization process model, international investment decision model.

\section{INTRODUCTION}

Researchers have described various internationalization processes for firms. Johanson and Vahlne [1] defined one of the first models of the internationalization process and showed that understanding the marketplace or having market knowledge is essential for making new commitments and redirecting business activities to exploit international opportunities. Among the various internationalization approaches, scholars either accept [2-5] or challenge [6] the international process model developed by Johanson and Vahlne [1,6]. Since Johanson and Vahlen's model integrates market knowledge, experience and the risk factors into a firm's internationalization process, their approach is consistent with generally accepted models used in the financial industry [7]. This research includes investment costs and the concepts of risk to expand the practical application of Johanson and Vahlne's early model.

Several sensitivity analysis techniques have been developed in the literature to describe and derive parameters of importance [8-12]. In this research, an international investment decision model is derived and sensitivity analysis is used to define and explain the key factors influencing the decision outcomes. Section 2 provides a literature review of the parameters commonly used to define international investment decision models. Section 3 transforms the Johanson and Vahlne formulation to include definitions favored by financial institutions loaning capital to firms expanding operations abroad. Section 4 and Section 5 discuss the research methodology and describe the sensitivity analysis results. Finally, Section 6 presents the discussion and conclusion.

\footnotetext{
*Address correspondence to this author at the Department of Business Administration, LungHwa University of Science and Technology, 300, Sec. 1, WanShou Rd., GuiShan Shiang, Taoyuan County 333, Taiwan; Tel: +886-282093211\#6512; Fax: +886-2-82093211\#6510;

E-mail: tsuiyii@mail.lhu.edu.tw; tsuiyii@gmail.com
}

\section{LITERATURE REVIEW}

In this section, the applications and challenges of the internationalization process model are introduced and the research milestones of international investment decision are identified. After these issues are discussed and related to the research, the model is revised as an investment cost and risk based international investment decision model.

\section{Application and Challenge of Internationalization Proc- ess Model}

The internationalization process model developed by Johanson and Vahlne (1977) is based on an analysis of the firm's market knowledge, market commitment, commitment decision and current activities [1]. The model emphasizes that a lack of knowledge about a foreign market of interest is a major obstacle to international investment operations. The accuracy of market knowledge leads to greater investment success whereas poor market knowledge increases the likelihood of a failed investment. Market commitment relates to activities of the firm that can restrict freedom of action [13]. The difficulty of transferring resources affects the degree of market commitment, and the more specialized the resource to the specific market, the greater the degree of commitment required [1]. According to Chetty and Eriksson (2002), experiential knowledge and market commitment dependent on the structure of the business network surrounding the parties and cannot be transferred between countries or between units in a firm [14]. Commitment decisions depend on the decision alternatives chosen and carried out [1].

Numerous researchers have extended or modified the internationalization process model. For example, Sullivan and Bauerschmidt (1990) conducted an empirical test of European forest product firms based on Johanson and Vahlne's model [2]. Lamb and Liesch (2002) re-framed the relationships between market knowledge, market commitment and market involvement [4]. They proposed an iterative model of internationalization for small firms where mar- 
ket knowledge and market commitment were reciprocally caused. Furthermore, Forsgren (2002) indicated that experiential learning positively influenced tacit knowledge [5]. The eclectic paradigm challenges conventional internationalization models and points out that ownership-specific advantages, transfer advantages, and location advantages play important roles in the internationalization process [15]. Dunning (2000) concludes that a dynamic component would make the eclectic paradigm a more useful analytical framework for examining internationalization [16].

In conclusion, regarding the operational activities of firms, internationalization behavior is often decided by a combination of learning through the experience and incorporation of members that have international knowledge [17]. Various operational activities, which come from different levels of market knowledge, market commitment, and commitment decisions, yield different investment costs and profits.

\section{Theory Development for the International Investment Decision Model}

Optimal investment and timing are achieved by managing the differences between the actual and expected rewards [17]. Firms execute investment strategies based on various considerations. Bacon (1992) derived investment decision techniques using net present value and the internal rate of return [18]. For a typical decision formulation under uncertainty, the decision makers choose the action which maximizes their expected utility via the various evaluations [19]. The best know methods are break-even analysis, sensitivity analysis, method, the theory of games, and decision making theory [20]. Bhandari (1981) also indicated that several methods incorporate risk and uncertainty including the certainty equivalent method, the risk-adjusted discount rate method, the simple average method, the expected value method, and sensitivity analysis [21].

To date, no comprehensive methodology for integrating risk considerations into management decision making has been derived. Methods such as scorecards, statistical analysis, and scenario have been applied but with limitations [22]. Using classical theory, risk reflects the variation in the distribution of achievable outcomes, their likelihoods, and their subjective values [4]. Expected value is supposed to be positively associated, and risk is assumed to be negatively associated with the attractiveness of an alternative [23]. Sarin and Weber (1993) provided a synthesis of the research on risk measurement and decision models based on expected utility and non-expected utility [24]. Modeling approaches selected by decision makers have a strong impact on the outcome. March and Shapira (1987) indicated that variation in the ways individuals perceive risk results from incentives and experience [23]. The attitude toward risk is important to consider in the corporate internationalization process. Although risk can be defined as an exposure to uncertainty, people judge uncertainty differently [25]. March and Shapira (1987) indicated that the definition of risk employed by executives who were responsible for organizational decisions differed radically from the variance measure used in the financial management field [23].
Referring to investment decision models, Howe and Patterson (1985) present a mixed integer programming formulation of the capital rationing problem [26]. Güven and Kaynarch (1998) developed a mixed integer investment and financial planning model which can be used for strategic planning [27]. Gori (1996) used linear and integer programming to make rational and consistent portfolio selections for projects undertaken in the Durban Metropolitan Region [28]. Their results indicated that the linear and integer programming model can be successfully used to ensure rational and consistent investment decisions are made over time as new projects are considered. In conclusion, because of the different tolerances of risk and the different risk attitudes, various industries or companies will set different risk coefficients or use different investment evaluation models. Based on above discussion, this research provides an integer programming model which integrates risk attitudes, expected values, and investment costs into the international investment decision for firms.

\section{MODEL TRANSFORMATION}

In this section, the Johanson and Vahlne's model is transformed into an international investment decision model including investment cost and attitude toward risk. There are four key items underlying Johanson and Vahlne's model (1977) - market knowledge, market commitment, commitment decision, and current activities [1]. The factors for market commitment include two state factors, the amount of resources committed and the degree of commitment. In order to clarify the roles of integrating the experience of the firm into the internationalization process, they distinguish between firm experience and market experience. Because of the performance of current activities, both experiences are necessary. For the commitment decision, Johanson and Vahlne (1977) distinguish between an economic effect and an uncertainty effect for each additional commitment [1]. The following equation describes the systems of relationships underlying Johanson and Vahlne's commitment decision strategy.

$\mathrm{R}_{\mathrm{i}}^{*}=$ Maximum tolerable market (market i) risk $=\mathrm{f}$ (firm's resource position, firm's risk approach)

$\mathrm{R}_{\mathrm{i}}=$ Market i risk situation

$=\mathrm{C}_{\mathrm{i}} * \mathrm{U}_{\mathrm{i}}$

where $\mathrm{C}_{\mathrm{i}}=$ Market $\mathrm{i}$ commitment $\mathrm{U}_{\mathrm{i}}=$ Market $\mathrm{i}$ uncertainty

Based on the above equations, companies should increase their investment scale when $\mathrm{R}_{\mathrm{i}}<\mathrm{R}_{\mathrm{i}}^{*}$ and implement an uncertainty-reducing strategy to seek for the opportunities to invest the market but withdraw from the market when $R_{i}>$ $\mathrm{R}_{\mathrm{i}}^{*}$. Risk wary decision makers prefer relatively low risks and are willing to sacrifice some expected return in order to reduce the variation in possible outcomes. Risk seeking decision makers prefer relatively high risks and are willing to sacrifice some expected returns in order to increase the variation of outcomes.

According to the discussion about risk averse and risks seeking behavior and the relationship between risk and ex- 
pected returns, this research uses integer programming to model Johanson and Vahlne's model but with additional parameters. The revised international investment model adopts $\mathrm{ER}_{\mathrm{j}}\left(\mathrm{P}_{\mathrm{ij}}\right.$ * Outcome $\left.\mathrm{ij}_{\mathrm{ij}}\right)$, Cost $\mathrm{j}_{\mathrm{j}}$ and $\mathrm{PR}_{\mathrm{j}}$ as the model parameters to replace market risk (market uncertainty $U_{i}$ and market commitment $\left.C_{i}\right)$ and firm's risk tolerance degree $\left(R_{i}^{*}\right)$ from the original model. The replacements are justified as follows. In practice, the sources of market information are varied, which causes difficulties for firms to precisely quantify the market risk. Further, the risk tolerance depends on the firm's investment decision experience, capital scale, and manager's subjective judgment. Therefore, the comparison between market risk $\left(\mathrm{R}_{\mathrm{i}}\right)$ and risk tolerance $\left(\mathrm{R}_{\mathrm{i}}^{*}\right)$ is difficult to quantify in practice. However, it is fairly easy to estimate the expect revenue of projects under market uncertainty $\left(\mathrm{U}_{\mathrm{i}}\right)$. $E R_{j}$ is defined as the expected revenue under the $\mathrm{j}^{\text {th }}$ market. When a firm can define or estimate the market knowledge needed for market entry decisions, then the task is to compute the expected revenue $\left(E_{\mathrm{j}}\right)$ to be derived from the estimated sales volume given the product price in the target market. The firm further evaluates the possibilities $\mathrm{PR}_{\mathrm{j}}$ of achieving the revenue in terms of the company's risk attitude (which replaces the measure of the firm's risk tolerance degree $\mathrm{R}_{\mathrm{i}}^{*}$ ). The risk attitude is used to weigh the risk factors after evaluating the market uncertainty using market knowledge and the firm's experience [29].

Market commitment defines the firm's involvement level and willingness to invest in a market and is quantified by evaluating Cost $_{\mathrm{j}}$, the investment cost of the $\mathrm{j}^{\text {th }}$ market. The higher the market commitment degree $\left(\mathrm{C}_{\mathrm{i}}\right)$, the higher the investment cost $\left(\mathrm{Cost}_{\mathrm{j}}\right)$ to enter a market. Investment cost may include factors such as transaction cost, management cost, operating cost, production cost, labor cost, coordination cost $[30,31]$, and other costs. Therefore, the cost variables may be numerous and expressed by a linear or non-linear function according to the firm's analytical approach. Hence, when the expected revenue, multiplied by the probability of achieving the revenue is greater than the investment cost, then the firm should invest in the market. The rule for deciding when to invest in a market is $\mathrm{PR}_{\mathrm{j}} * \mathrm{ER}_{\mathrm{j}} \geqq$ Cost $\mathrm{t}_{\mathrm{j}}$. The revised investment decision model is derived as follows.

Maximize $\pi=\sum_{\mathrm{j}=1}^{\mathrm{n}}\left[\mathrm{PR}_{\mathrm{j}} *\left(\sum_{\mathrm{i}=1}^{\mathrm{m}}\left(\right.\right.\right.$ Outcome $\left.\left.\left._{\mathrm{ij}} * \mathrm{P}_{\mathrm{ij}}\right)\right)-\operatorname{Cost}_{\mathrm{j}}\right] * \mathrm{Iv}_{\mathrm{j}}$

Subject to

$\sum_{\mathrm{j}=1}^{\mathrm{n}}\left(\operatorname{Cost}_{\mathrm{j}} * \operatorname{Iv}_{\mathrm{j}}\right) \leq \operatorname{Cost}_{\mathrm{F}}$

$\mathrm{Iv}_{\mathrm{j}}=(0,1)$

$\sum_{\mathrm{i}=1}^{\mathrm{m}} \mathrm{P}_{\mathrm{i} .}=1$

$0 \leq \mathrm{P}_{\mathrm{ij}} \leq 1$

$0 \leq \mathrm{PR}_{\mathrm{j}} \leq 1$

$\mathrm{i}=1,2,3, \ldots ., \mathrm{m}$

$j=1,2,3, \ldots ., n$

where:
$\operatorname{Cost}_{\mathrm{j}}=$ the investment costs for a given market.

$\operatorname{Cost}_{\mathrm{F}}=$ the total restricted investment cost for all the markets considered by firm.

$I v_{j}=$ the decision to invest $\left(I v_{j}=1\right)$ or withdraw $\left(I v_{j}=0\right)$ from a market.

$\mathrm{i}=$ the number of different types of risk in a given market.

$j=$ the number of different markets.

Outcome $_{i j}=$ the possible outcome under condition $i$ and $j$ market.

$P_{i .}=$ the sum of probabilities under the Outcome $e_{i j}$ condition when market $j$ is fixed.

$\mathrm{P}_{\mathrm{ij}}=$ the prior probabilities of Outcome $\mathrm{ij}_{\mathrm{ij}}$ vary with market information and market knowledge.

$\mathrm{PR}_{\mathrm{j}}=$ the achievable probabilities of $\mathrm{ER}_{\mathrm{j}}$ vary with the investors' risk attitudes.

The integer-programming problem is solved using Lingo and Excel software [7]. The example sets all variables except for $I v_{j}$ and the value of $I v_{j}$ determines whether or not to invest in the project. After confirming $\mathrm{Iv}_{\mathrm{j}}$, the company derives the maximum values $\pi$ and the total cost. Therefore, the values of $P R_{j}$ vary depending on the firms' risk attitudes. The risk wary investor, when facing a high risk market, sets a lower value for $\mathrm{PR}_{\mathrm{j}}$ to evaluate the market $\mathrm{j}$ investment decision and expects stable investment returns. On the contrary, the risk taker sets a higher $\mathrm{PR}_{\mathrm{j}}$ and expects a higher investment return. Even though the prior probability and the possible outcomes are equal for the same market situation, the investment decisions vary based on the firm's risk attitudes. Furthermore, if the firms assign more Cost $_{\mathrm{F}}$ to their investment project, their investment decisions change accordingly. To confirm the revised international investment decision model, interviews were conducted with two international financial holding company managers [7]. The managers applied the model for decision making and agreed that the revised model helped their companies develop and adjust their investment strategy using risk attitudes and associated cost variables.

\section{RESEARCH METHODOLOGY}

In addition to transforming the internationalization process model into the international investment decision model, sensitivity analysis was conducted to clarify the influence of risk attitudes and investment costs. For model confirmation, Eschenbach (1989) indicated that approaches for dealing with uncertain data include deterministic approximations, expected value analysis, simulation, and sensitivity analysis [32]. All of these techniques are used to improve decisionmaking, determine which data estimates should be refined, or focus managerial attention on the key elements during implementation. Sensitivity analysis has become a key method in testing the correctness and corroborating the robustness of models in several disciplines [33]. When firms deal with investment projects, many factors are uncertain. The basic purpose of investment sensitivity analysis is not only to gain insight into the impact of parameter changes to criteria values, but to understand the impact of these changes 
on the total evaluation of the investment projects validity $[20,34]$. Researchers can determine factors to perform the sensitivity analysis in decision-making and implementation process. This method helps planners understand differences in decision-making under changeable variables. Hence, based on these results, sensitivity analysis is used to discuss the degree of importance for parameter changes to the international investment decision model.

\section{RESEARCH RESULTS}

For the revised international investment model, the $\mathrm{PR}_{\mathrm{j}}$ values differ with risk attitude. Risk wary investors assign lower $\mathrm{PR}_{\mathrm{j}}$ values to assess the market investment decisions and increase their chances of obtaining stable profits in highrisk markets while investors with a high risk tolerance assign higher $\mathrm{PR}_{\mathrm{j}}$ values and expect higher investment profits. Although the $P_{i j}$ and Outcome ${ }_{i j}$ values are similar within markets, investment decisions vary according to differences in risk attitude among firms. Holding the market the same, the investment decision changes according to the different Cost $_{j}$ values and investment scale. Hence, this research uses these values to demonstrate the sensitivity analysis of $\mathrm{PR}_{\mathrm{j}}$ and Cost $t_{j}$ variables.

\section{Sensitivity Analysis of Risk Attitude}

The different risk attitudes are defined as $\mathrm{PR}_{\mathrm{j}}$, the prior probabilities of various possible outcomes are defined as $\mathrm{P}_{\mathrm{ij}}$, the possible outcome under various conditions and markets as Outcome $\mathrm{i}_{\mathrm{ij}}$, and the investment cost for a given market as Cost $\mathrm{j}_{\mathrm{j}}$. According to the discussion in the literature review, the degree of market risk is measured using the variation in expected outcomes and the market investment risk increases with the variation in Outcome $\mathrm{ij}_{\mathrm{ij}}$. In order to analyze the possible situations in investment decision-making, the input parameters are varied against the various risk attitudes. The sensitivity analysis of risk attitudes with fixed prior probabilities, possible outcomes, and investment costs follows.

\section{Parameters}

$\mathrm{PR}_{\mathrm{jk}} \quad$ The achievable probabilities of $\mathrm{ER}_{\mathrm{j}}$ vary with $\mathrm{k}^{\text {th }}$ risk attitudes of investors in market $\mathrm{j} . \mathrm{j}=1 \ldots \mathrm{n} ; \mathrm{k}=1 \ldots \mathrm{t}$.

$\triangle \mathrm{PR}_{\mathrm{j}} \quad$ The $\mathrm{PR}_{\mathrm{j}}$ increment of investors in market $\mathrm{j}$. The measurement unit is percentage. $\Delta P R_{j}=\left[P R_{j(k+1)}-P R_{j k}\right] / P_{j k}$

Profit ratio $\mathrm{jk}_{\mathrm{j}}$ The profit ratio vary with $\mathrm{k}^{\text {th }}$ risk attitude of investors and specific investment cost in market $\mathrm{j} . \mathrm{j}=1 \ldots \mathrm{n} ; \mathrm{k}=1 \ldots \mathrm{t}$.

If investors increase their risk attitudes for the investment projects, then the variation in the rate of profit ratio is described as follows.
Profit ratio $_{j(\mathrm{k}+1)}-$ Profit ratio $_{\mathrm{jk}}$

$=\frac{\left(\mathrm{PR}_{\mathrm{j}(\mathrm{k}+1)} * \mathrm{ER}_{\mathrm{j}}-\mathrm{Cost}_{\mathrm{j}}\right)}{\operatorname{Cost}_{\mathrm{j}}}-\frac{\left(\mathrm{PR}_{\mathrm{j} \mathrm{k}} * \mathrm{ER}_{\mathrm{j}}-\mathrm{Cost}_{\mathrm{j}}\right)}{\mathrm{Cost}_{\mathrm{j}}}$

$=\frac{E R_{j}}{\operatorname{Cost}_{j}}\left(P R_{j(k+1)}-P R_{j k}\right)$

$=\frac{\mathrm{PR}_{\mathrm{j}}{ }^{*} \mathrm{ER}_{\mathrm{j}}}{\mathrm{Cost}_{\mathrm{j}}} *\left(\Delta \mathrm{PR}_{\mathrm{j}}\right) \cdots \cdots$ We ignore parameter $\mathrm{k}$ and

generalize the equation in this step.

$=$ Profit ratio $_{\mathrm{j}} * \Delta \mathrm{PR}_{\mathrm{j}}$

So,

$\Delta$ Profit ratio $_{\mathrm{j}}=\Delta \mathrm{PR}_{\mathrm{j}}$

$\Delta \mathrm{PR}_{\mathrm{j}} \uparrow \Rightarrow$ Profit ratio $\uparrow$

The sensitivity analysis is conducted using Excel software as shown in Table 1. Based on the risk seeking behaviors of a firm, the different values of $\mathrm{PR}_{\mathrm{j}}$ and the profit ratios are calculated. The higher the risk seeking behaviors of firms, the higher is the risk and return of the market under consideration.

Table 1. Sensitivity Analysis of Risk Attitude in Specific Markets

\begin{tabular}{|c|c|c|c|c|}
\hline \multirow{2}{*}{$\mathbf{P R}_{\mathrm{jk}}{ }^{\mathrm{a}}$} & \multicolumn{4}{|c|}{ Profit Ratio $_{\mathbf{j k}}{ }^{\mathrm{b}}$} \\
\hline & Market $1^{c}$ & Market 2 & . & Market n \\
\hline $\mathrm{PR}_{\mathrm{j} 1}$ & Profit ratio $_{11}$ & Profit ratio 21 & . & Profit ratio $_{n 1}$ \\
\hline $\mathrm{PR}_{\mathrm{j} 2}$ & Profit ratio $_{12}$ & Profit ratio $_{22}$ & . & Profit ratio $_{n 2}$ \\
\hline $\mathrm{PR}_{\mathrm{j} 3}$ & Profit ratio $_{13}$ & Profit ratio $_{23}$ & . & Profit ratio $_{n 3}$ \\
\hline . & . & & . & \\
\hline . & . & . & . & \\
\hline $\mathrm{PR}_{\mathrm{jt}}$ & Profit ratio $_{1 t}$ & Profit ratio $2 t$ & . & Profit ratio ${ }_{n t}$ \\
\hline
\end{tabular}

Note: The shaded segments in Table 1 represent the investment decisions considered by firms.

${ }^{\mathrm{a}} \mathrm{PR}_{\mathrm{jk}}$ : The $\mathrm{k}^{\text {th }}$ risk attitude of investors in market $\mathrm{j} . \mathrm{k}=1$...t.

${ }^{\mathrm{b}}$ Profit ratio $\mathrm{j}_{\mathrm{jk}}=\left(\mathrm{PR}_{\mathrm{jk}}{ }^{*} \mathrm{ER}_{\mathrm{j}}-\mathrm{Cost}_{\mathrm{j}}\right) / \operatorname{Cost}_{\mathrm{j}}$.

${ }^{c}$ Market 1 represents the highest risk and investment return market. Market 2 represents the second risk and investment return market, etc.

Using the analytical approach of Table 1, the following example assumes that the firm considers investment in two markets. The values of $\mathrm{P}_{\mathrm{ij}}$, Outcome $\mathrm{i}_{\mathrm{ij}}$, and Cost $\mathrm{t}_{\mathrm{j}}$ of market 1 (high risk and high return) and market 2 (low risk and low return) are listed and calculated as follows.

Market 1: The two different values of $\mathrm{P}_{\mathrm{ij}}$ and Outcome $\mathrm{i}_{\mathrm{ij}}$ for market 1 are $(0.3$, NT\$ 800,000) and $(0.7$, NT\$ $-250,000)$ with Cost $_{j}$ equal to NT $\$ 25,000$. These data can be used to calculate $\mathrm{ER}_{\mathrm{j}}$ as equal to NT $\$ 65,000$ with a variance $_{j}$ of $2.315 \mathrm{E}+11$. 
Market 2: The values of $\mathrm{P}_{\mathrm{ij}}$ and Outcome $\mathrm{ij}_{\mathrm{ij}}$ of market 2 are $(0.7, \mathrm{NT} \$ 80,000)$ and $(0.3, \mathrm{NT} \$-10,000)$ with a Cost $_{j}$ of NT\$ 25,000. The ER ${ }_{j}$ equals $\$ 53,000$ with a variance ${ }_{j}$ of $1.70 \mathrm{E}+09$.

Table 2. Risk Attitude and Profit Ratio Sensitivity Analysis for Market 1 and Market 2

\begin{tabular}{|c|c|c|}
\hline \multirow{2}{*}{$\mathbf{P R}_{\mathrm{j}}$} & \multicolumn{2}{|c|}{ Profit Ratio $_{j k}=\left(\mathrm{PR}_{\mathrm{jk}}{ }^{*} \mathrm{ER}_{\mathrm{j}}-\operatorname{Cost}_{\mathrm{j}}\right) /$ Cost $_{\mathrm{j}}$} \\
\hline & Market 1 & Market 2 \\
\hline 0.1 & $-0.74^{\mathrm{a}}$ & $-0.79^{b}$ \\
\hline 0.2 & -0.48 & -0.58 \\
\hline 0.3 & -0.22 & -0.36 \\
\hline 0.4 & 0.04 & -0.15 \\
\hline 0.5 & 0.30 & 0.06 \\
\hline 0.6 & 0.56 & 0.27 \\
\hline 0.7 & 0.82 & 0.48 \\
\hline 0.8 & 1.08 & 0.70 \\
\hline 0.9 & 1.34 & 0.91 \\
\hline
\end{tabular}

Note: The shaded segments represent the investment decisions considered by firm.

${ }^{\mathrm{a}}=(0.1 * 65,000-25,000) / 25,000=-0.74 .^{\mathrm{b}}=(0.1 * 53,000-25,000) / 25,000=-0.79$.

Under the cost restrictions, the risk assessment and decision making for two markets is studied. Based on the above assumptions, the values of $\mathrm{ER}_{\mathrm{j}}$ and Variance $\mathrm{V}_{\mathrm{j}}$ for market 1 exceed those for market 2 with market 1 having a higher risk than market 2 . From example 1, the firm individually assesses market 1 and 2 using subjective factors. When the values of $P_{\mathrm{jk}}$ range from 0.1 to 0.9 , the firm uses the sensitivity analysis of the revised investment decision model.
From Table 2, for the same market, the lower the given $\mathrm{PR}_{\mathrm{j}}$ values in market 1 but higher $P_{\mathrm{j}}$ values in market 2 , the higher the firm's risk wariness. Meanwhile, a firm's risk tolerance and expected profit increases with increasing $P_{\mathrm{j}}$ value in market 1 but decreases in market 2 . Furthermore, Fig. (1) shows that the market has no investment values when the profit ratio is below zero (see the dotted line in Fig. (1)). When the $P_{1 k}$ value of market 1 exceeds 0.384 (profit ratio equals zero) and the $\mathrm{PR}_{2 \mathrm{k}}$ value of market 2 exceeds 0.471 , then the two markets hold investment value. To obtain higher investment profit ratios for firms, then the investment value of market 1 should exceed that of market 2 based on the same risk attitude.

\section{Sensitivity Analysis of Investment Cost}

This section details the sensitivity analysis of investment cost with fixed prior probabilities, possible outcomes, and risk attitudes. Using the example 1 , the analysis uses the cost factors as defined below.

Parameters

Cost $_{\mathrm{jg}}$

$\Delta \operatorname{Cost}_{j}$

Profit ratio $_{j k g} \quad$ The profit ratio with $g^{\text {th }}$ type cost situa-

The $\mathrm{g}^{\text {th }}$ type cost situations of investment cost considered for a given market j. $\mathrm{j}=1 \ldots \mathrm{n} ; \mathrm{g}=1 \ldots \mathrm{v}$.

The Cost $_{j}$ increment of investors in market $\mathrm{j}$. The measurement unit is percentage. $\Delta$ Cost $_{\mathrm{j}}=\left[\operatorname{Cost}_{\mathrm{j}(\mathrm{g}+1)}-\operatorname{Cost}_{\mathrm{jg}}\right] /$ Cost $_{\mathrm{j}}$ tion and $\mathrm{k}^{\text {th }}$ risk attitude of investors in market j. $g=1 \ldots v ; k=1 \ldots t ; j=1 \ldots n$.

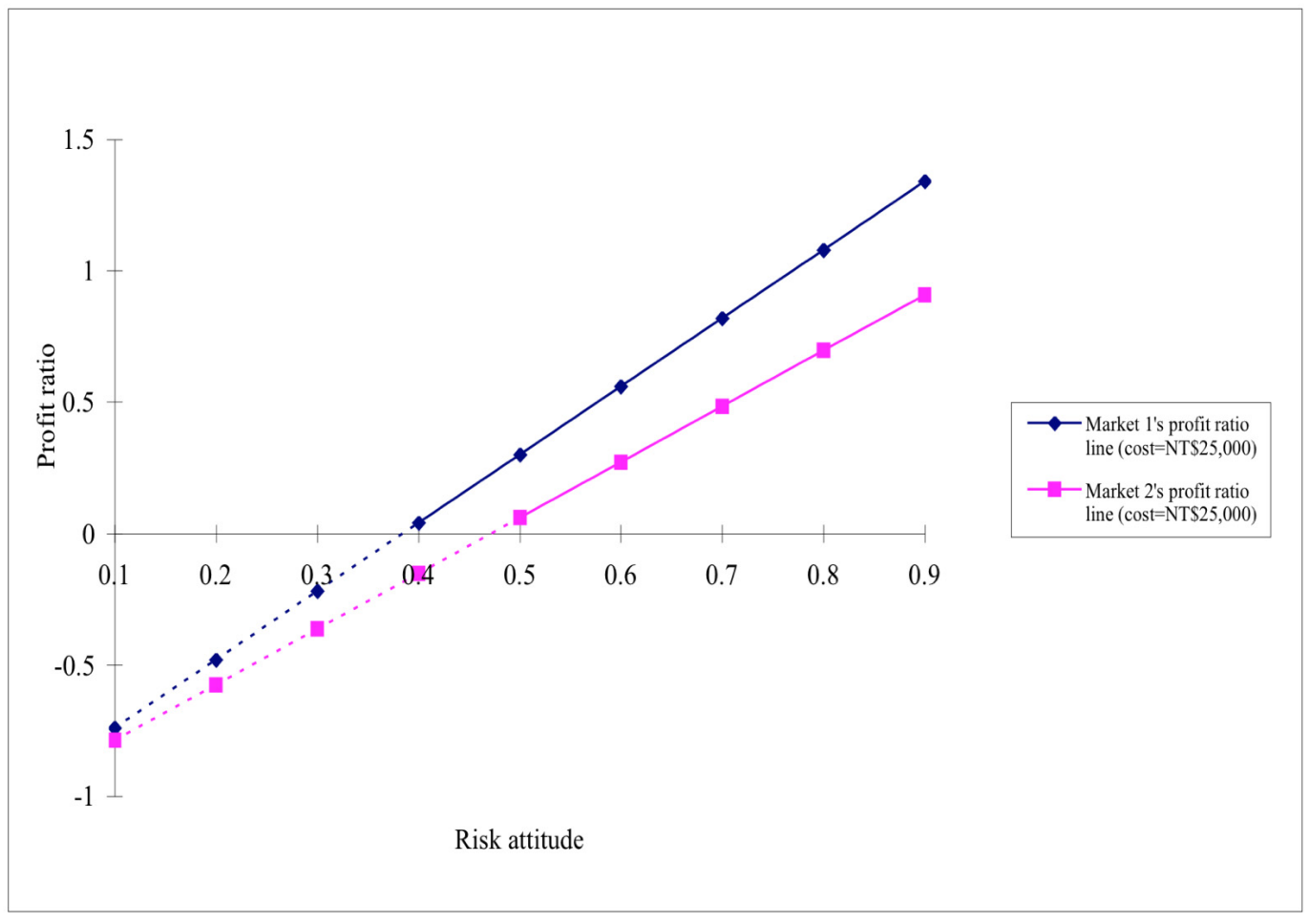

Fig. (1). The relationship between risk attitude and the profit ratio. 
If investors increase their investment cost when evaluating investment projects, then the variation in the profit ratio is computed as follows.

Profit ratio $_{\mathrm{jk}(\mathrm{g}+1)}-$ Profit ratio $_{\mathrm{jkg}}$

$=\frac{\left(\mathrm{PR}_{\mathrm{jk}} * \mathrm{ER}_{\mathrm{j}}-\operatorname{Cost}_{\mathrm{j}(\mathrm{g}+1)}\right)}{\operatorname{Cost}_{\mathrm{j}(\mathrm{g}+1)}}-\frac{\left(\mathrm{PR}_{\mathrm{jk}} * \mathrm{ER}_{\mathrm{j}}-\operatorname{Cost}_{\mathrm{jg}}\right)}{\operatorname{Cost}_{\mathrm{jg}}}$

$=\mathrm{PR}_{\mathrm{jk}} * \mathrm{ER}_{\mathrm{j}} *\left(\frac{\operatorname{Cost}_{\mathrm{jg}}-\operatorname{Cost}_{\mathrm{j}(\mathrm{g}+1)}}{\operatorname{Cost}_{\mathrm{jg}} * \operatorname{Cost}_{\mathrm{j}(\mathrm{g}+1)}}\right)$

$=\mathrm{PR}_{\mathrm{j}} * \mathrm{ER}_{\mathrm{j}} *\left(\frac{-\Delta \operatorname{Cost}_{\mathrm{j}} * \operatorname{Cost}_{\mathrm{j}}}{\operatorname{Cost}_{\mathrm{j}} *\left(1+\Delta \operatorname{Cost}_{\mathrm{j}}\right) * \operatorname{Cost}_{\mathrm{j}}}\right) \cdots$ We ignore

parameters $\mathrm{k}$ and $\mathrm{g}$ and generalize the equation in the step.

$$
\begin{aligned}
& =\frac{\operatorname{PR}_{\mathrm{j}} * \mathrm{ER}_{\mathrm{j}}}{\operatorname{Cost}_{\mathrm{j}}} *\left(\frac{-\Delta \operatorname{Cost}_{\mathrm{j}}}{1+\Delta \operatorname{Cost}_{\mathrm{j}}}\right) \\
& =\text { Profit ratio }_{\mathrm{j}} *\left(\frac{-\Delta \operatorname{Cost}_{\mathrm{j}}}{1+\Delta \operatorname{Cost}_{\mathrm{j}}}\right)
\end{aligned}
$$

So,

$\Delta$ Profit ratio $_{\mathrm{j}}=\frac{-\Delta \text { Cost }_{\mathrm{j}}}{1+\Delta \text { Cost }_{\mathrm{j}}}$

$\Delta$ Cost $_{\mathrm{j}} \uparrow \Rightarrow$ Profit ratio $\downarrow$

For analyzing the possible outcomes in investment decision-making, the input parameters are varied using the related cost factors. The resulting sensitivity analysis is shown in Table 3.

Referring to example 1, market 1 (high risk and high return) has a higher investment value than market 2 (low risk and low return) under restricted values of $\mathrm{PR}_{\mathrm{j}}, \mathrm{Cost}_{\mathrm{j}}$ and riskseeking behavior. However, given variations in the cost or scale of the investment, the final decision may differ even if the values of $\mathrm{P}_{\mathrm{ij}}$, Outcome $\mathrm{i}_{\mathrm{ij}}$ and $\mathrm{PR}_{\mathrm{j}}$ are the same. The following example assumes that the value of the investment cost ranges from NT $\$ 25,000$ to NT $\$ 50,000$. The interval value is NT\$5000 and there are six situations for which the profit ratios are calculated. Tables $\mathbf{4}$ and $\mathbf{5}$ indicate that the profit ratio decreases with increasing investment cost. With the same $P_{\mathrm{j}}$ and with the same cost increment in the two markets, the investment in market 1 is greater than that of market 2. Even if the $P_{\mathrm{j}}$ of a firm is fixed at 0.7 , the tolerable cost increment is NT $\$ 20,000$ rather than NT $\$ 10,000$ for market 2. The results of the profit ratios for market 1 are based on six cost values. The profit ratio line of Market 2 is set with a restricted cost of NT $\$ 25,000$. For Fig. (2), if the investment cost for market 1 is below NT $\$ 30,000$, then the firm invests in market 1 or market 2 (investment cost is NT $\$ 25,000$ ).

According to example 1, the sensitivity analysis demonstrates that when $\mathrm{PR}_{\mathrm{j}}$ is reduced to 0.1 , the reduced profit ratio of market 1 is 0.26 and the reduced profit ratio of market 2 is 0.212 (see the comparative results in Tables $\mathbf{4}$ and $\mathbf{5}$ ). Furthermore, when Cost $_{j}$ is increased by NT $\$ 5,000$, the range of decrease in the profit ratio for market 1 increases the $P R_{j}$ value. That is, when the market $1 P R_{j}$ value is 0.1 , the profit range decreases from 0.04 (the Cost $_{j}$ increases from NT $\$ 25,000$ to NT $\$ 30,000$ ) to 0.01 (the Cost increases $_{j}$ from NT\$45,000 to NT\$50,000). Moreover, when the $\mathrm{PR}_{\mathrm{j}}$ value for market 1 is 0.9 , the range of reduction in the profit ratio is from 0.39 (with an increase in Cost $t_{j}$ from NT $\$ 25,000$ to NT $\$ 30,000$ ) to 0.13 (the Cost increases from NT $\$ 45,000$ to NT $\$ 50,000)$. The data distribution for market 2 is the same as that of market 1 (Table 5). The influence degree of Cost $t_{j}$ on the profit ratio increases with the increase in the $P_{j}$ value. Comparing the values between $\Delta \mathrm{PR}_{\mathrm{j}}$ and $\Delta \operatorname{Cost}_{\mathrm{j}} /\left(1+\Delta \operatorname{Cost}_{\mathrm{j}}\right)$, if $\Delta \mathrm{PR}_{\mathrm{j}}=\Delta \operatorname{Cost}_{\mathrm{j}}=\lambda$, then the value $\lambda$ is more than the value of $\lambda /(1+\lambda)$. Thus, in comparison to the cost factors, the influence of risk attitude is the most important to the firms' international investment decision.

Table 3. Sensitivity Analysis of Investment Cost and Profit

\begin{tabular}{|c|c|c|c|c|c|c|}
\hline \multirow{3}{*}{$\begin{array}{c}\text { Market j } \\
\text { Profit } \\
\text { Ratio }_{\mathrm{jkg}}\end{array}$} & \multirow{3}{*}{$\mathbf{P R}_{\mathbf{j k}}{ }^{\mathrm{a}}$} & \multicolumn{5}{|c|}{ Investment Cost Unit: NT\$ Dollars } \\
\hline & & \multicolumn{5}{|c|}{ Investment Cost $\left(\right.$ Cost $\left._{\mathrm{jg}}\right)$} \\
\hline & & $\operatorname{Cost}_{\mathbf{j} 1}{ }^{\mathrm{c}}$ & $\operatorname{Cost}_{\mathbf{j} 2}$ & $\operatorname{Cost}_{\mathbf{j} 3}$ & . & $\operatorname{Cost}_{\mathbf{j v}}$ \\
\hline & $\mathrm{PR}_{\mathrm{j} 1}$ & $\begin{array}{l}\text { Profit } \\
\text { ratio }_{j 11}\end{array}$ & $\begin{array}{l}\text { Profit } \\
\text { ratio }_{j 12}\end{array}$ & Profit ratio $_{j 13}$ & & Profit ratio $_{j 1 \mathrm{v}}$ \\
\hline & $\mathrm{PR}_{\mathrm{j} 2}$ & $\begin{array}{l}\text { Profit } \\
\text { ratio }_{j 22}\end{array}$ & $\begin{array}{l}\text { Profit } \\
\text { ratio }_{j 22}\end{array}$ & Profit ratio $_{\mathrm{j} 23}$ & & Profit ratio $_{\mathrm{j} 2 \mathrm{v}}$ \\
\hline & $\mathrm{PR}_{\mathrm{j} 3}$ & $\begin{array}{l}\text { Profit } \\
\text { ratio }_{j 31}\end{array}$ & $\begin{array}{l}\text { Profit } \\
\text { ratio }_{j 32}\end{array}$ & Profit ratio ${ }_{j 33}$ & & Profit ratio $_{\mathrm{j3v}}$ \\
\hline & $\mathrm{PR}_{\mathrm{jt}}$ & $\begin{array}{l}\text { Profit } \\
\text { ratio }_{j t 1}\end{array}$ & $\begin{array}{l}\text { Profit } \\
\text { ratio }_{\mathrm{j} 22}\end{array}$ & Profit ratio $_{\mathrm{jt} 3}$ & & Profit ratio $_{\mathrm{jtv}}$ \\
\hline
\end{tabular}
Ratio in A Given Market

Note: The shaded segments in the Table 3 represent the investment decision considered by firms.

${ }^{a} \mathrm{PR}_{\mathrm{jk}}$ : The $\mathrm{k}^{\text {th }}$ risk attitude of varied investors in market $\mathrm{j} . \mathrm{k}=1 \ldots \mathrm{t}$.

${ }^{\mathrm{b}}$ Profit ratio $_{\mathrm{jkg}}=\left(\mathrm{PR}_{\mathrm{jk}}{ }^{*} \mathrm{ER}_{\mathrm{j}}-\mathrm{Cost}_{\mathrm{jg}}\right) / \operatorname{Cost}_{\mathrm{jg}} . \mathrm{G}=1 \ldots \mathrm{v} ; \mathrm{k}=1 \ldots \mathrm{t} ; \mathrm{j}=1 \ldots \mathrm{n}$.

${ }^{c} \operatorname{Cost}_{\mathrm{j} 1}$ means the initial investment cost in market $\mathrm{j}$. Cost $\mathrm{j}_{\mathrm{j} 2}$ means the initial investment cost plus the cost increment in market $\mathrm{j}$.

The analytical results demonstrate that the $\mathrm{PR}_{\mathrm{j}}$ and Cost ${ }_{\mathrm{j}}$ influence the optimal solution of the international investment decision model. That is, even though the $\mathrm{ER}_{\mathrm{j}}$ value of market 1 is higher than that of market 2, market 1 has a higher profit ratio than market 2. With the increase in Cost value is high enough to allow the calculated profit ratio to exceed zero, it is still worthwhile to invest. The $E_{\mathrm{j}}$ value of market 2 is lower than that of market 1 . Therefore, the increased investment cost of market 2 easily exceeds the firm's tolerance degree and the computed profit ratio is below zero. Simultaneously, despite the $\mathrm{PR}_{\mathrm{j}}$ value being 0.9 , the firm still does not invest in market 2 .

Johanson and Vahlne indicated that reducing market uncertainty or market commitment would help firms reduce investment costs and increase international investment aspirations. That is, if the risk tolerance degree $R_{i}^{*}$ is sufficiently 
high to let $\mathrm{R}_{\mathrm{i}} \leq \mathrm{R}_{\mathrm{i}}^{*}$, then the probability of firms making a positive international investment is increased. The sensitivity analysis of the revised international investment decision model indicates that both firm risk attitude and investment cost exert significant influence on the final investment decision. If the investor increases the value of $\mathrm{PR}_{\mathrm{j}}$ or decreases the value of Cost $_{j}$ while keeping the profit ratio greater than zero, then the probability of investing increases.

Table 4. Market 1 Sensitivity Analysis of Risk Attitude, Investment Cost and Profit Ratio

\begin{tabular}{|ccccccccc|}
\hline & \multicolumn{6}{c|}{ Investment Cost Unit: NT\$ dollars } \\
\hline $\begin{array}{c}\text { Market 1 } \\
\text { Profit } \\
\text { Ratio }_{1 \mathrm{~kg}}\end{array}$ & PR $_{\mathbf{1 k}}$ & \multicolumn{6}{c|}{ Investment Cost (Cost $\mathbf{1 g}_{\mathbf{g}}$ ) } \\
\cline { 2 - 8 } & $\mathbf{2 5 , 0 0 0}$ & $\mathbf{3 0 , 0 0 0}$ & $\mathbf{3 5 , 0 0 0}$ & $\mathbf{4 0 , 0 0 0}$ & $\mathbf{4 5 , 0 0 0}$ & $\mathbf{5 0 , 0 0 0}$ \\
\hline \hline & 0.1 & -0.74 & -0.78 & -0.81 & -0.84 & -0.86 & -0.87 \\
& 0.2 & -0.48 & -0.57 & -0.63 & -0.68 & -0.71 & -0.74 \\
& 0.3 & -0.22 & -0.35 & -0.44 & -0.51 & -0.57 & -0.61 \\
& 0.4 & 0.04 & -0.13 & -0.26 & -0.35 & -0.42 & -0.48 \\
& 0.5 & 0.3 & 0.08 & -0.07 & -0.19 & -0.28 & -0.35 \\
& 0.6 & 0.56 & 0.30 & 0.11 & -0.03 & -0.13 & -0.22 \\
& 0.7 & 0.82 & 0.52 & 0.30 & 0.14 & 0.01 & -0.09 \\
& 0.8 & 1.08 & 0.73 & 0.49 & 0.30 & 0.16 & 0.04 \\
& 0.9 & 1.34 & 0.95 & 0.67 & 0.46 & 0.30 & 0.17 \\
\hline
\end{tabular}

Note: The shaded segments express the investment ranges for the values of $\mathrm{PR}_{\mathrm{jk}}$ and Costjg.

\section{DISCUSSION AND CONCLUSION}

Managers have expressed dissatisfaction with traditional net present value (NPV) or discounted cash flow (DCF) techniques since the cash flow must be forecast over the expected time of the future profits, taxation policy, exchange rates, and political climate [35]. The appropriate riskadjusted discount factor must be obtained and most firms seldom change the discount rate to match the increased risk. In spite of these shortcomings, using a firm's characteristics to establish a specific risk evaluation system is important for building a profitable investment strategy. Sensitivity analysis yields a great deal of information about the effect of input parameters on the examined criteria for investment project decision making [20]. In our model, the $\mathrm{PR}_{\mathrm{j}}$ and Cost $\mathrm{j}_{\mathrm{j}}$ significantly influence the international investment decision. Moreover, $\mathrm{PR}_{\mathrm{j}}$ is more influential than Cost ${ }_{\mathrm{j}}$ and the analytical results demonstrate the crucial importance of the risk attitudes of firms. In addition to risk attitude, differences in market information and market uncertainty influence the estimates of prior probabilities, expected revenue and investment costs of firms. Hence, if firms cannot accurately forecast market variations and make investment decisions based simply on their risk attitude, then forecast error and profit loss will likely occur. The research limitations of this study are described as follows. First, parameters in the model simulation are given fixed values but in practice parameters for decision-making are varied and uncertain. Second, the risk factors vary with the decision maker's opinion. Finally, the results of the sensitivity analysis indicate that the risk attitude of firms has a higher degree of influence than investment cost. Consequently, the risk attitude of the final decision maker can drive the international investment decision. The international investment decision model helps investors make decisions using computer based simulations. The model is simple and the variables are general and easily adapted by decision makers. Although the parameters in the simulation used fixed and subjective values, the equations differentiate between the two parameters of risk attitude and cost provided in the study. Therefore, the generalizeability of the model is supported. Future research can enlarge the revised model and variables choices, using sensitivity analysis

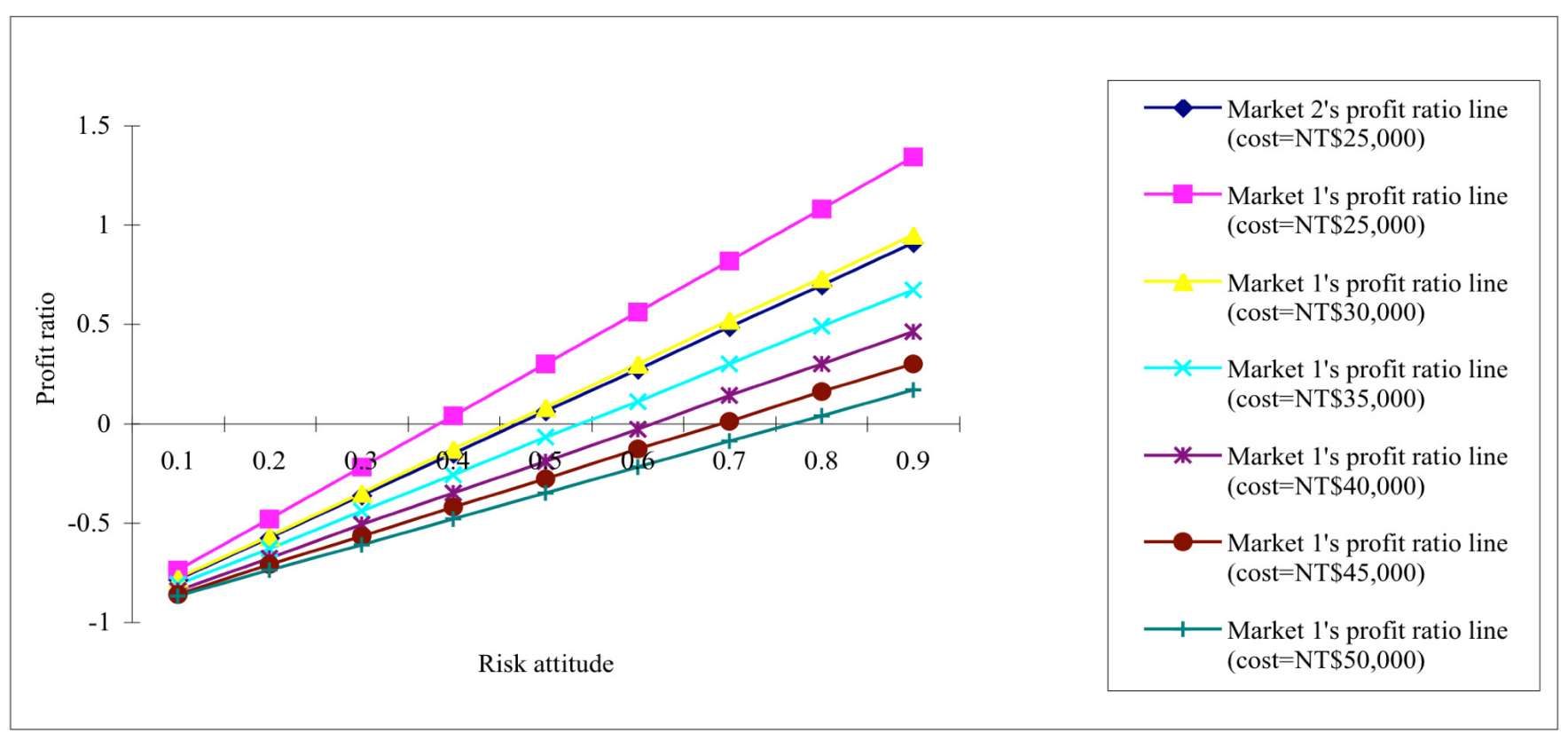

Fig. (2). The comparative diagram of risk attitude and profit ratio given various investment costs and markets. 
to evaluate the decision making processes across different industry sectors.

Table 5. Market 2 Sensitivity Analysis of Risk Attitude, Investment Cost and Profit Ratio

\begin{tabular}{|c|c|c|c|c|c|c|c|}
\hline \multirow{3}{*}{$\begin{array}{c}\text { Market } 2 \\
\text { Profit } \\
\text { Ratio }_{2 \mathrm{~kg}}\end{array}$} & \multicolumn{7}{|c|}{ Investment Cost Unit: NT\$ Dollars } \\
\hline & \multirow{2}{*}{$\mathbf{P R}_{2 \mathrm{k}}$} & \multicolumn{6}{|c|}{ Investment Cost $\left(\right.$ Cost $\left._{2 \mathrm{~g}}\right)$} \\
\hline & & 25,000 & 30,000 & 35,000 & 40,000 & 45,000 & 50,000 \\
\hline & 0.1 & -0.79 & -0.82 & -0.85 & -0.87 & -0.88 & -0.89 \\
\hline & 0.2 & -0.58 & -0.65 & -0.70 & -0.74 & -0.76 & -0.79 \\
\hline & 0.3 & -0.36 & -0.47 & -0.55 & -0.60 & -0.65 & -0.68 \\
\hline & 0.4 & -0.15 & -0.29 & -0.39 & -0.47 & -0.53 & -0.58 \\
\hline & 0.5 & 0.06 & -0.12 & -0.24 & -0.34 & -0.41 & -0.47 \\
\hline & 0.6 & 0.27 & 0.06 & -0.09 & -0.21 & -0.29 & -0.36 \\
\hline & 0.7 & 0.48 & 0.24 & 0.06 & -0.07 & -0.18 & -0.26 \\
\hline & 0.8 & 0.70 & 0.41 & 0.21 & 0.06 & -0.06 & -0.15 \\
\hline & 0.9 & 0.91 & 0.59 & 0.36 & 0.19 & 0.06 & -0.05 \\
\hline
\end{tabular}

Note: The shaded segments express the investment ranges for the values of $\mathrm{PR}_{\mathrm{jk}}$ and Cost $_{\mathrm{jg}}$.

\section{REFERENCES}

[1] Johanson J, Vahlne JE. The internationalization process of the firm-a model of knowledge development and increasing foreign market commitments. J Bus Stud 1977; 8(1): 23-32.

[2] Sullivan D, Bauerschmidt A. Incremental internationalization: A test of Johanson and Vahlne's thesis. Manag Int Rev 1990; 30(1): 19-30.

[3] Erramilli MK, Srivastava R, Kim SS. International theory and Korean multinationals. Asia Pac J Manag 1999; 16: 29-45.

[4] Lamb PW, Liesch PW. The internationalization process of the smaller firm: Re-farming the relationships between market commitment, knowledge and involvement. Manag Int Rev 2002; 42(1): 7-26.

[5] Forsgren M. The concept of learning in the Uppsala internationalization process model: A critical review. Int Bus Rev 2002; 11(3): $257-77$.

[6] Johanson J, Vahlne JE. The mechanism of internationalization. Int Market Rev 1990; 7(4): 11-24.

[7] Trappey CV, Shih TY, Trappey AJC. Modeling international investment decisions for financial holding companies. Eur J Oper Res 2007; 180: 800-14.

[8] Helton JC. Uncertainty and sensitivity analysis techniques for use in performance assessment for radioactive waste disposal. Reliab Eng Syst Saf 1993; 42: 327-67.

[9] Cheok MC, Parry GW, Sherry RR. Use of importance measures in risk-informed regulatory applications. Reliab Eng Syst Saf 1998; 60: 213-26.

[10] Turanyi T, Rabitz H. Local methods. In: Saltelli A, Chan K, Scott EM, Eds. Sensitivity Analysis. Chichester: Wiley 2000; pp. 81-9.
[11] Koltai T, Terlaky T. The difference between the managerial and mathematical interpretation of sensitivity analysis results in linear programming. Int J Prod Econ 2000; 65(3): 257-74.

[12] Borgonovo E, Peccati L. Uncertainty and global sensitivity analysis in the evaluation of investment projects. Int J Prod Econ 2006; 104(1): 62-73.

[13] Helliar CV, Lonie AA, Power DM, Sinclair CD. Managerial attitudes to risk: a comparison of Scottish chartered accountants and U.K. managers. J Int Acc Audit Taxation 2002; 11: 165-90.

[14] Chetty S, Eriksson K. Mutual commitment and experiential knowledge in mature international business relationship. Int Bus Rev 2002; 11(3): 305-24

[15] Dunning JH. The eclectic paradigm of international production: A restatement and some possible extensions. J Int Bus Stud 1988; 19(1): 1-31.

[16] Dunning JH. The eclectic paradigm as an envelope for economic and business theories of MNE activity. Int Bus Rev 2000; 9: 16390.

[17] Ekboir JM. Technical change an irreversible investment under risk. Agric Econ 1997; 16: 55-65.

[18] Bacon CJ. The use of decision criteria in selecting information systems/technology investment. MIS Q 1992; 16(3): 335-53.

[19] Hederstierna A. Decisions under uncertainty: A note on skewed uncertainty distributions. Omega Int J Manag Sci 1981; 9(4): 4423.

[20] Jovanovic P. Application of sensitivity analysis in investment project evaluation under uncertainty and risk. Int J Proj Manag 1999; 17(4): 217-22.

[21] Bhandari NC. Capital expenditure decisions under risk and uncertainty. Adv Manag J 1981; 46(4): 52-61.

[22] Bekefi T, Epstein M. Risk - getting the whole picture. CMA Manag 2007; 180(8): 23-6.

[23] March JG, Shapira Z. Managerial perspective on risk and risktaking. Manag Sci 1987; 33(11): 1404-18.

[24] Sarin RK, Weber M. Risk-value models. Eur J Oper Res 1993; 70 : 135-49.

[25] Holton G. Subjective value at risk. Financial Engineering News, August 1997.

[26] Howe KM, Patterson JH. Capital investment decisions under economies of scale in flotation costs. Financ Manag 1985; 14(3): 61-9.

[27] Güven S, Kaynarch A. An integrated investment and financial planning model. Int Trans Oper Res 1998; 5(2): 123-36.

[28] Gori E. Portfolio selection of capital investment projects in the Durban Metropolitan Region. Construct Manag Econ 1996; 14(5): 451-6.

[29] Wu G, Gonzalez R. Curvature of the probability weighting function. Manag Sci 1996; 42(12): 1676-90.

[30] Chen H, Chen TJ. Network linkages and location choice in foreign direct investment. J Int Bus Stud 1998; 29(3): 445-66.

[31] Zekos GI. MNEs, globalization and digital economy: Legal and economic aspects. Manag Law 2003; 45(1/2): 1-296.

[32] Eschenbach, TG. Improved sensitivity analysis for project justification. Proceedings of the $33^{\text {rd }}$ Annual Meeting of the American Association of Cost Engineers 1989; June: B. 4.1- B.4.7.

[33] Borgonovo E, Peccati L. Sensitivity analysis in investment project evaluation. Int J Prod Econ 2004; 90(1): 17-25.

[34] Ray A. Cost-Benefit analysis. Baltimore: The Johns Hopkins University Press 1987; p. 37.

[35] Moyen N, Slade M, Uppal R. Valuing risk and flexibility: a comparison of methods. Resour Policy 1996; 22(1/2): 63-74.

This is an open access article licensed under the terms of the Creative Commons Attribution Non-Commercial License (http://creativecommons.org/licenses/by$\mathrm{nc} / 3.0 /$ ) which permits unrestricted, non-commercial use, distribution and reproduction in any medium, provided the work is properly cited. 